\title{
Utilization of biodiesel derived-glycerol for 1,3-PD and citric acid production
}

\author{
Laura Mitrea ${ }^{1}$, Monica Trif ${ }^{1}$, Adriana-Florinela Cătoi ${ }^{2}$ and Dan-Cristian Vodnar ${ }^{1 *}$ (1)
}

\begin{abstract}
Today, biofuels represent a hot topic in the context of petroleum and adjacent products decrease. As biofuels production increase, so does the production of their major byproduct, namely crude glycerol. The efficient usage of raw glycerol will concur to the biodiesel viability. As an inevitable waste of biodiesel manufacturing, glycerol is potentially an attractive substrate for the production of value-added products by fermentation processes, due to its large amounts, low cost and high degree of reduction. One of the most important usages of glycerol is its bioconversion through microbial fermentation to value-added materials like 1,3-propanediol and citric acid. There is a considerable industrial interest in 1,3-propanediol and citric acid production based on microbial fermentations, as it seems to be in competition with traditional technologies utilized for these products. In the present work, yields and concentrations of 1,3-propanediol and citric acid registered for different isolated strains are also described. Microbial bioconversion of glycerol represents a remarkable choice to add value to the biofuel production chain, allowing the biofuel industry to be more competitive. The current review presents certain ways for the bioconversion of crude glycerol into citric acid and 1,3-propanediol with high yields and concentrations achieved by using isolated microorganisms.
\end{abstract}

Keywords: Biodiesel, Crude glycerol, 1, 3-PD, Citric acid, Strains, Fermentation

\section{Introduction and background Biodiesel}

Due to the continuously growing of world industrial output, every quantity of energy is needed. This energy is provided through biological, chemical, electrochemical or physical ways and mechanisms, starting from natural resources. One of these natural resources is well-known as petroleum and its byproducts, like petrol, diesel, gasoline, etc. Due to the increased fuels demands on the market, these natural resources present some negative aspects because of the global ecological imbalance they have created. In this respect, an alternative fuel source is strongly necessary [1]. There are some researches which underline that petroleum production will decrease gradually until 2050, and the reserves are thought to become completely exhausted by then. Taking these into account,

\footnotetext{
*Correspondence: dan.vodnar@usamvcluj.ro

${ }^{1}$ Department of Food Science, Faculty of Food Science and Technology, Institute of Life Sciences, University of Agricultural Sciences and Veterinary Medicine Cluj-Napoca, Calea Mănăştur 3-5, 400372 Cluj-Napoca, Romania Full list of author information is available at the end of the article
}

the demand for alternative fuels is growing worldwide and the use of biomass for producing biofuels is one of the most promising choices so far $[2,3]$.

Biofuels represent a variety of combustibles which derive from biomass. In Europe, the best known biofuel is biodiesel. This particular type of fuel is created from animal fats, vegetable oils or recycled greases [4]. Biodiesel can be characterized as long chains of alkyl esters, which are formed by transesterification reaction (Scheme 1) of triglycerides with alcohol resulting in glycerol as a byproduct [1]. During the biofuels manufacturing process, a great amount of residue is generated-in particularly glycerol-fact which leads to a negative aspect concerning the price of biodiesel. A general ratio between the biodiesel production and the amount of generated residual glycerol, points that for every 10 parts of biodiesel, one part of glycerol is produced [5-7].

\section{Crude-glycerol (CG), a byproduct of biodiesel production Crude glycerol, in most cases, can be obtained in two ways: hydrolytically from oils and fats by soaps and fatty acids production, or by transesterification of fats or oils}



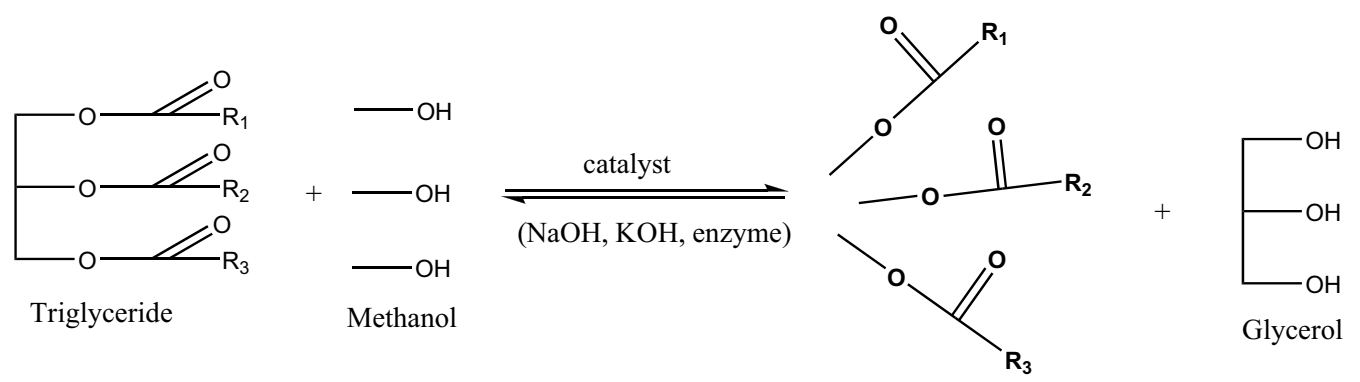

Methil / alkyl esters (BIODIESEL)

Scheme 1 The general transesterification reaction of triglycerides in order to obtain biodiesel and glycerol

with an alcohol in the presence of a catalyst during the production of biodiesel. In the second method, the catalyst involved in the transesterification reaction may be an acid, a base, or an enzyme. Most often, base catalysts widely used are $\mathrm{NaOH}$ or $\mathrm{KOH}[6,7]$. After the transesterification reaction [3] and separation of crude biodiesel, crude glycerol is not pure enough for a direct use in different applications $[8,9]$. In order to defeat this problem, impurities must be removed by an effective and very efficient purification process, to minimize the production costs and waste [8].

Biodiesel derived-glycerol also contains two substrates, namely glycerol and fatty acids. Hypothetical, these compounds can be used both simultaneously as well as gradually. In a study conducted by Morgunov and Kamzolova [9] it is presented that some specific strains are able to use both glycerol and fatty acid fractions during fermentation processes, even glycerol is consumed at a more elevated rate than fatty acids [9].

Glycerol, similar to multiple other small and uncharged molecules, can pass through the cytoplasmic membrane of different microorganisms. This passing occurs through passive diffusion. Many strains are able to develop on glycerol as a carbon source, due to the fact that this substrate can be both oxidatively and reductively metabolized through dehydrogenase or dehydratase. In this respect, by using yeast, bacterial and fungal strains, lots of value-added metabolic compounds could be obtained through microbial fermentation of glycerol, such as: acetic acid, lactic acid, propionic acid, citric acid, succinic acid, oxalic acid, butanol, propanediol, mannitol, ethanol, dihydroxyacetone, single-cell oil, biomass, polyunsaturated fatty acids, etc. (Scheme 2) [10-13].

The biodiesel production process implies a glycerin phase obtained as by-product. This phase contains glycerol, methanol, mono- and diaceloglycerols, fatty acids $[4,9]$, and soaps. Some statistics reveal that impressive quantities of glycerin phase are generated each year (at least 200-300 tons, up to hundreds of thousand tons per year), depending on the biodiesel production industry of each country. This fact leads to environmental problems regarding the management of this by-product [4, 10]. An appropriate solution to this threat is the usage of crude glycerol or glycerin phase as a carbon source for microbial growth media used in the production of various types of metabolites, for example 1,3-PD, citric acid, lactic acid, propionic acid, succinic acid and dihydroxyacetone $[4,11,15]$. The conversion of CG into value added products represents a strategy for the economic recycle of waste, and an approach for utilization of raw glycerol as a source for production of different industrial valueadded products [1].

From the chemical point of view, pure glycerol is a liquid substance with no odor or color, which is hygroscopic and viscous with a vague sweet taste. Industrially obtained raw glycerol, is a light brown semi solid substance resulted as waste of biodiesel production [16]. Glycerol presents three hydrophilic alcoholic hydroxyl groups, which make it responsible for its good solubility in water and give it hygroscopic properties [7]. Glycerol density is $1.261 \mathrm{~kg} / \mathrm{L}$, it has a melting point of $18.2{ }^{\circ} \mathrm{C}$, and a boiling point of $290{ }^{\circ} \mathrm{C}$ under pure anhydrous condition and normal atmospheric pressure [14]. In terms of ecological toxicity, the thermal degradation of glycerol at high levels of temperature $\left(280-300{ }^{\circ} \mathrm{C}\right)$ can produce acrolein which is a poisonous compound for living organisms. That is to say, even a small quantity of acrolein (approximately $2 \mathrm{ppm}$ ) exerts strong toxicity [14]. In this context, the utilization of crude glycerol as a nutrient broth for bacteria appears as a viable future prospects [1]. Glycerol has many other applications in different areas; it is largely used as commodity chemical in pharmaceutical industry and in the production of dyes, cosmetics, soaps, toothpaste, lubricants, food, antifreeze solutions, etc. $[6,17]$. The enormous amounts of glycerol resulted from manufacturing of biodiesel make the utilization of CG cheaper, as a carbon source, compared with glucose. More than that, glucose is directly implied in food 


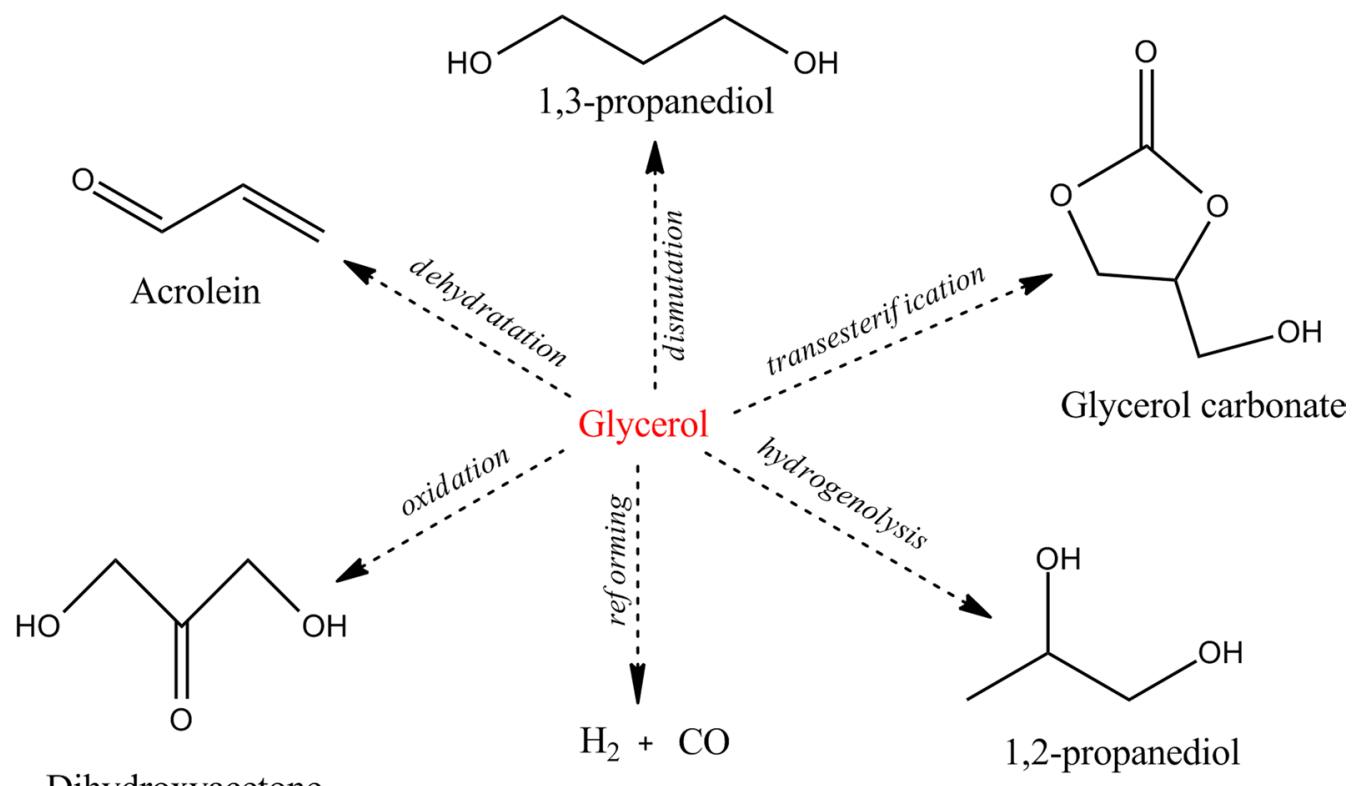

Dihydroxyacetone

Scheme 2 Possible pathways of glycerol degradation [14]; various products can be obtained

production, while glycerol is not, which makes it a feasible carbon source for various fermentations $[1,14]$.

In the field of biochemistry, glycerol performs a fundamental role in the stabilization of enzymes due to its polyhydric alcohol functions. This fact generally enhances the structural stability of the entire protein, by maintaining the equilibrium of the hydrophilic-lipophilic profile (HLB) which is achieved by means of protein adsorption. It can be concluded that glycerol presents a major importance, as this compound also secures the biological compounds during sol-gel entrapment in matrices based on silica, by forming poly-glyceryl silicate as sol-gel precursors, or by addition in direct way to the microorganisms preceding the sol-gel poly-condensation [7].

\section{The bioconversion of glycerol to 1,3-propanediol (1,3-PD)}

From the chemical point of view 1,3-propanediol is also named trimethylene glycol, 1,3-dihydroxypropane, or propane-1,3-diol. Its molecular formula is $\mathrm{C}_{3} \mathrm{H}_{8} \mathrm{O}_{2}$, and it has a molecular mass of $76.09 \mathrm{~g} \times \mathrm{mol}^{-1}$. 1,3-PD's boiling point is $210-212{ }^{\circ} \mathrm{C}$ and the melting point is $-28^{\circ} \mathrm{C}$ $[4,18]$. 1,3-PD represents a specific product of glycerol fermentation, and it is a chemical intermediate largely used in the manufacture of polymers (polyethers, polyesters, polyurethanes), drugs, cosmetics, lubricants, and is also used as a mediator in the synthesis of heterocyclic compounds [3, 4, 19]. Recent studies reveal that 1,3PD is often used as a monomer to synthesize a new type of biodegradable polyester, namely polytrimethylene terephthalate (PTT), which is more environmentally friendly and holds better properties then other plastic materials, like polyethylene terephthalate (PET) or polybutylene terephthalate (PBS) $[6,19,20]$.

From a metabolic point of view, glycerol is fermented through dismutation [2] which involves two collateral pathways. There is one pathway where crude or pure glycerol is transformed into dihydroxyacetone by a glycerol dehydrogenase, and there is another one where a coenzyme B12-dependent glycerol dehydratase transforms glycerol to 3-hydroxypropionaldehyde. In the last mentioned pathway, 3-hydroxypropionaldehyde is reduced to 1,3-PD by the 1,3-propanediol dehydrogenase $\mathrm{NAD}^{+}$dependent enzyme (Scheme 3), under the consumption of reducing power $\left(\mathrm{NADH}_{2}\right)$ [3]. The $\mathrm{NADH}_{2}$ generated through the glycerol metabolism leads to the formation of various byproducts using the important glycolysis reactions [21]. Moreover, the $\mathrm{NADH}_{2}$ supplementation and regeneration are critical in order to obtain great yields and concentrations of 1,3-PD [22]. In this way, many other metabolites can be obtained from glycerol, considering the two fermentation pathways (dihydroxyacetone, 2,3-butanediol, acetic acid, propionic acid, succinic acid, citric acid, lactic acid, docosahexanoic acid, hydrogen, ethanol) $[1,4,6,19,21,22]$.

The chemical synthesis of 1,3-propanediol can be conducted by two significant processes. The first one is "Degussa" (hold by "DuPont Company") and implies catalytically oxidation of propylene to acrolein, which is hydrated next to 3-hydroxypropionaldehyde at medium 


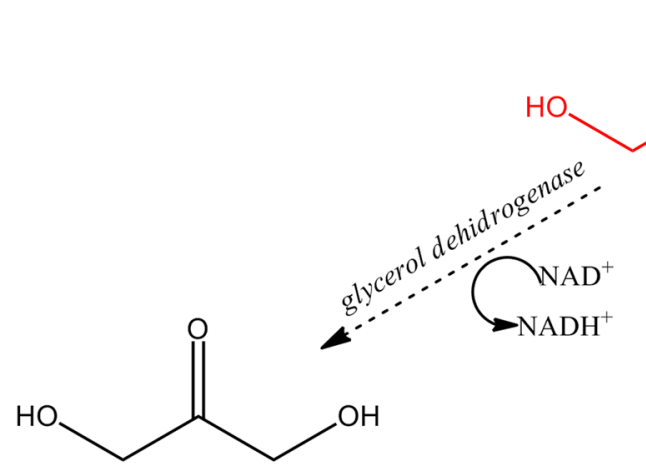

dihydroxyacetone

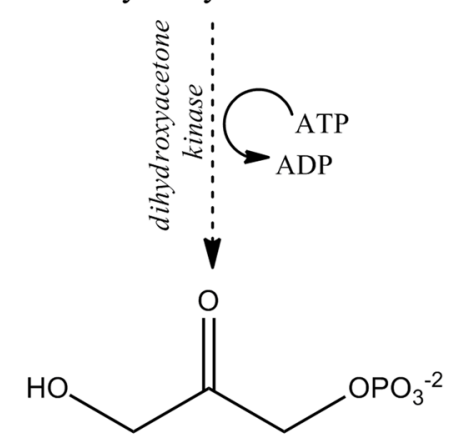

dihydroxyacetone-p

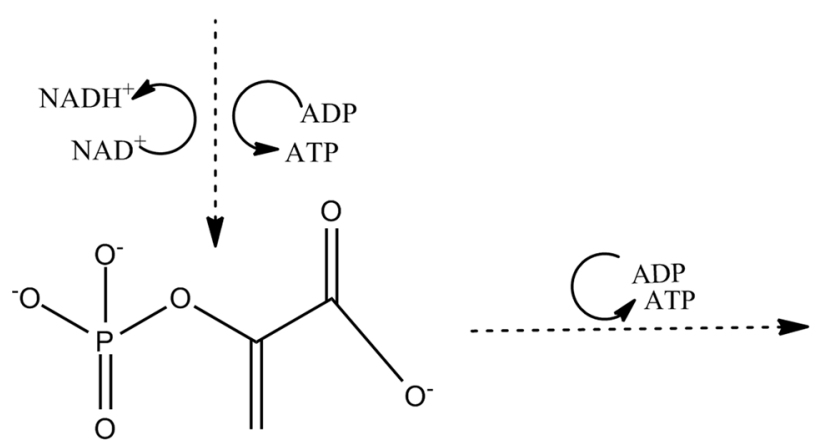

phosphoenolpyruvate

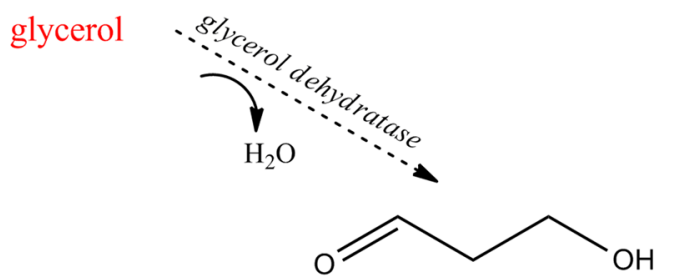

3-hydroxypropionaldehyde

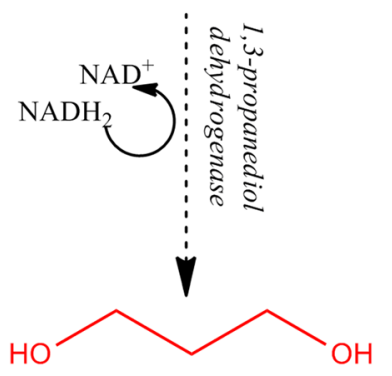

1,3-propanediol

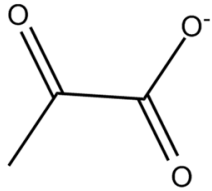

pyruvate

Scheme 3 Collateral pathways of glycerol fermentation [4, 19, 23]; the mechanism of 1,3-PD production

pressure and temperature, followed by the hydrogenation to 1,3-PD using a rubidium catalyst at high pressure. The second process carried out by "Shell" is based on oxidation of ethylene to ethylene oxide, followed by production of 3-hydroxypropionaldehyde through the reaction called "hydroformylation" (also named "oxo synthesis") at high pressures (around 150 bar). The aldehyde extraction from the organic phase is performed using water, and the 3-hydroxypropionaldehyde hydrogenation is conducted by using nickel as a catalyst under high pressure. The production of 1,3-PD registers a conversion yield between 65 and $80 \%$ when acrolein and ethylene oxide are used as raw material $[21,24]$.
For the quantification of kinetic behavior (like cell growth, substrate assimilation, final product synthesis) of able microorganisms to convert pure or crude glycerol directly to 1,3-PD, modeling approaches were used for different wild strains [25-28]. Some authors described the glycerol bioconversion to 1,3-PD by showing a series of chemical reactions along with some mathematical equations regarding the biomass yield [25, 26, 28], substrate consumption and 1,3-PD production rates [28]. In their studies, Papanikolaou and others $[27,28]$ simulated a modified Monod's equation, namely the Contois-type model, capable to predict the production of biomass and 1,3-PD from glycerol by wild Clostridium butyricum F2b 
in fed-batch cultivations [27]. Using Contois-type model was found that the maximum theoretical productivity of 1,3-PD was comparable with the highest one obtained during growth of various bacterial strains cultivated on pure glycerol in batch and fed-batch cultures [27].

More and more, new approaches for natural production of 1,3-PD are deeply studied. The employment of microorganisms to produce 1,3-PD from crude glycerol represents one important topic for the research field. A generous number or microorganisms can develop anaerobically on glycerol, as nutrient and energy source. In present, several strains acting as biocatalysts are used and well investigated for 1,3-PD production. We can mention some examples of good 1,3-PD producers: K. pneumoniae, $K$. oxytoca, K. planticola, C. freundii, Cl. butyricum, L. brevis, L. buchneri etc. [6, 29].

\section{KLEBSIELLA's 1,3-PD production}

Among the strains of Enterobacteriaceae, K. pneumoniae seems to give the best results in 1,3-PD production. In order to obtain good results, $\mathrm{Mu}$ et al. [6] proposed an integrated bioprocess combining biodiesel production via lipase, with microbial production of $1,3-\mathrm{PD}$ by K. pneumoniae DSM 2026, using a hollow fiber membrane [6]. During the process, the microorganism has converted glycerol directly to 1,3-PD, with the following results: the final concentration of 1,3-PD was about $61.1 \mathrm{~g} / \mathrm{L}$, the molar yield was $0.51 \mathrm{~mol} / \mathrm{mol}$, and the volumetric productivity of $1,3-\mathrm{PD}$ was $2.0 \mathrm{~g} / \mathrm{L} / \mathrm{h}$. There was also mentioned the maximum theoretical yield of 1,3-PD to glycerol, which was $0.72 \mathrm{~mol} / \mathrm{mol}$ under anaerobic conditions [6].

Classical reports also show that wild Klebsiella strains are potential producers for relatively important values of 1,3-propanediol. A study conducted by Menzel et al. [26] in 1997 points that K. pneumoniae DSM 2026 produces about 35.2-48.5 g/L of 1,3-PD with theoretical maximum yield of $0.721 \mathrm{~mol} / \mathrm{mol}$ and a volumetric productivity ranging between 4.9 and $8.8 \mathrm{~g} / \mathrm{L} / \mathrm{h}$, in a continuous and anaerobic fermentation of glycerol [26].

Another research revealed that Rossi et al. [30] tested a consortium of bacteria in order to find a productive strain for 1,3-PD and ethanol from crude glycerol as a carbon source. Consequently, Klebsiella pneumoniae $\mathrm{BLh}^{-1}$ seems to give best results in degradation of CG. The consumption of CG was entirely performed within $32 \mathrm{~h}$ of cultivation in anaerobic conditions in a bioreactor, with a production of 1,3-PD of $19.9 \mathrm{~g} / \mathrm{L}$, and a theoretical yield of $0.72 \mathrm{~mol}$ product $/ \mathrm{mol}$ glycerol. The same paper suggests that $K$. pneumoniae $\mathrm{BLh}^{-1}$ gives similar results on pure glycerol too, as carbon source, realizing a production of $22.8 \mathrm{~g} / \mathrm{L}$ of $1,3-\mathrm{PD}$, with yields $(\mathrm{Yp} / \mathrm{s})$ of $0.68 \mathrm{~mol} \mathrm{product} / \mathrm{mol}$ glycerol [30].
From many points of view, $K$. pneumoniae is one of the most investigated and efficient microorganisms for 1,3-PD production from crude or pure glycerol. A newly isolated strain, namely $K$. pneumoniae GLC29 was intimately investigated by Da Silva et al. [31]. Beside glycerol concentration, the effects of some parameters as $\mathrm{pH}$, temperature and stirrer speed on the production and productivity of 1,3-propanediol were also evaluated. Considering both production and productivity, the best conditions for conversion of glycerol in 1,3-propanediol are as follows: a $\mathrm{pH}$ range of 6.9-7.1, a temperature between 33 and $38.5^{\circ} \mathrm{C}$, a stirrer speed range of 110-180 rpm, and a glycerol concentration of $39-49 \mathrm{~g} / \mathrm{L}$. The batch fermentation performed at a $\mathrm{pH}$ of 7.0, a temperature of $35^{\circ} \mathrm{C}$, a stirrer speed of $150 \mathrm{rpm}$, and a glycerol concentration of $40 \mathrm{~g} / \mathrm{L}$ produced $20.4 \mathrm{~g} / \mathrm{L}$ of $1,3-\mathrm{PD}$, with a maximal volumetric productivity of $2.92 \mathrm{~g} / \mathrm{L} / \mathrm{h}$ and a yield of $0.51 \mathrm{~g} / \mathrm{g}$. Few byproducts were obtained, like acetic acid (approximately $7.0 \mathrm{~g} / \mathrm{L}$ ) and formate (approximately $3.7 \mathrm{~g} / \mathrm{L}$ ). It can be concluded that the novel K. pneumoniae GLC29 showed potential for the conversion of glycerol into 1,3-propanediol, with high production yields and productivity [31].

Strains as Klebsiella oxytoca were reported by Garlapati et al. [1] to transform crude-glycerol into 1,3-PD under batch and fed-batch fermentation conditions with a yield and productivity ranging from 0.41 to $0.53 \mathrm{~g} / \mathrm{mol}$, respectively from 0.63 to $0.83 \mathrm{~g} / \mathrm{L} / \mathrm{h}[1]$.

\section{CLOSTRIDIUM's 1,3-PD production}

Few studies regarding the bioconversion of CG into 1,3PD using strains from Clostridium genus, have been reported. Some researches reveal that Clostridium butyricum F2b leads to good results [32], and produce important amounts of 1,3-propanediol on crude glycerol as a carbon source, in a continuous mode. Papanikolaou and others [32] grew C. butyricum F2b microorganisms on crude glycerol used as sole substrate, at concentrations of 39 and $90 \mathrm{~g} / \mathrm{L}$. The biomass production observed ranged between 1.2 and $2.6 \mathrm{~g} / \mathrm{L}$, while the productivity of 1,3-PD reached a maximum concentration of $47.1 \mathrm{~g} / \mathrm{L}$, and was the principal metabolic product [32]. Papanikolaou et al. [28] suggest that raw glycerol is a suitable source for the development of C. butyricum F2b and 1,3-PD production, in batch and single-stage continuous cultures. They underline that high intake of substrate concentrations positively influence the synthesis of 1,3$\mathrm{PD}$, favoring the production of organic acids like acetic acid and butyric acid. This fact is considered to be due to the organic acids metabolic pathway, which is a competitive and alternative pathway to that of 1,3-PD in the microbial cell [28]. 
A spore forming and anaerobic wild-strain, namely Clostridium species IK124, was tested by Hirchmann et al. [33] to evaluate its potential of using the untreated glycerol from biodiesel industry as a main substrate for 1,3-PD production. During fed-batch fermentation they combined the low base-driven glycerol addition with the constant glycerol measurement and a feedback regulation. Using this strategy and the Clostridium IK124 the results were significantly high (final 1,3-PD concentration: $87 \mathrm{~g} / \mathrm{L}$; productivity: $2,2 \mathrm{~g} / \mathrm{L} / \mathrm{h}$; yield: $65 \%$ [mol/ mol]) [33].

Clostridium butyricum strain VPI 1718 was investigated by Chatzifragkou et al. [34] in order to evaluate the production of 1,3-PD on crude glycerol as carbon source, and the impact of various impurities that can be found in CG derived from biodiesel production. The preliminary trials in $200 \mathrm{~mL}$ anaerobic flasks revealed that the presence of salts might influence the cell growth. Salts like $\mathrm{NaCl}$ (4.5\% w/w of glycerol) imposed an evident inhibitory effect in the growth medium, while phosphoric salts did not. Anyhow, $\mathrm{NaCl}$ appeared to show no influence on large quantities pending batch bioreactor experiments [up to $30 \%$ (w/w of glycerol)], and the microbial growth and 1,3-PD production are not affected by this compound. In this respect, C. butyricum VPI 1718 possesses significant tolerance capacity against specific salt quantities found in crude glycerol. Moreover, the presence of methanol did not influence the bacterial bioconversion of glycerol to 1,3-PD, even when relatively high concentrations $(10 \%, \mathrm{w} / \mathrm{w}$, of glycerol) were imposed in batch-reactor fermentations. Methanol was added, during continuous experiments, when steady state had been accomplished. Even though a high concentration of methanol was added into the fermenter $(5 \mathrm{~g} / \mathrm{L})$, the system gained a steady state without indicating any of the negative effects over biomass production due to the presence of alcohol [34]. By comparison of the biochemical response of the bacteria during utilization of pure or crude glycerol, it can be noticed that crude glycerol had no conspicuous effect on C. butyricum VPI 1718 in respect to both microbial growth and 1,3-PD production. Specifically, by the time of the continuous operation, 1,3-PD production recorded $14.1 \mathrm{~g} / \mathrm{L}$, reaching a volumetric productivity of $1.41 \mathrm{~g} / \mathrm{L} / \mathrm{h}$. At this dilution rate, important glycerol uptake was noticed, yielding a value of $1.08 \mathrm{~g} / \mathrm{g} / \mathrm{h}[34]$.

The same strain, C. butyricum VPI 1718, was tested [35] during a fed-batch operation under non-sterile fermentation conditions. Crude glycerol was employed as a nutrient source. The final concentration of 1,3-PD was $69.7 \mathrm{~g} / \mathrm{L}$, with an yield of $0.55 \mathrm{~g} / \mathrm{g}$, and a maximum volumetric productivity of $1.87 \mathrm{~g} / \mathrm{L} / \mathrm{h}$ [35]. More than that, the bioreactor's geometry and the effect of anaerobiosis strategy over the biochemical response of C. butyricum VPI 1718 were analyzed during 1,3-PD production [36]. It seems that the strain VPI 1718 can successfully produce 1,3-PD in the presence of $\mathrm{N}_{2}$ gas infusion whatever the initial glycerol concentration and bioreactor size are imposed [36].

Wilkens et al. [37] achieved good results regarding the biodiesel derived glycerol conversion to 1,3-propanediol, with Clostridium butyricum AKR102a. In a fed-batch fermentation, under anaerobic conditions, they obtained $93.7 \mathrm{~g} / \mathrm{L}$ of 1,3-PD with an yield of $0.632 \mathrm{~mol} / \mathrm{mol}$, and an overall productivity of $3.3 \mathrm{~g} / \mathrm{L} / \mathrm{h}$ by using pure glycerol as the nutrient source. Using crude glycerol as the substrate under the same conditions, $76.2 \mathrm{~g} / \mathrm{L}$ of $1,3-\mathrm{PD}$ was produced with a yield of $0.622 \mathrm{~mol} / \mathrm{mol}$, and a productivity of $2.3 \mathrm{~g} / \mathrm{L} / \mathrm{h}$ [37].

Xin et al. [20] combined two sources of nutrient substrates in order to enhance the productivity of 1,3-PD. Therefore, they used lignocellulosic hydrolysates (glucose, xylose, and arabinose) in an anaerobic fermentation, as co-substrates for the increasing yield of glycerol conversion to 1,3-PD. The three mentioned sugars were used, separately but concomitantly with glycerol, in the production of 1,3-PD by a Clostridium diolis DSM 15410. The results were situated between 18 and $28 \%$, meaning an increase in the 1,3-PD yield [20]. Beside the fact that glycerol is used as the sole carbon source in different fermentation processes, an addition of lowcost raw materials as co-nutrients may decrease the expenses of 1,3-PD production costs. There can be mentioned that glycerol is transformed in different metabolites during the dismutation process, via reductive and oxidative branches. The first one (reductive branch) determines 1,3-PD production with the consumption of $\mathrm{NADH}$, and the glycerol is oxidized to metabolites such as $\mathrm{H}_{2}, \mathrm{CO}_{2}$, acetate, butyrate, lactate, ethanol, butanol, or 2,3-butanediol. On this pathway energy is produced and the cell growth is reduced, facts which lead to the decrease of 1,3-PD production. Moreover, when glycerol is utilized as the sole nutrient substrate, the conversion yield of glycerol to 1,3-PD ranges usually under $0.72 \mathrm{~mol} / \mathrm{mol}$ (the theoretical yield) [20]. Xin et al. [20] point that the co-utilization of glycerol and glucose as carbon sources increases the cell growth, and at the same time, the production of 1,3-PD, which reaches to $14.7 \mathrm{~g} / \mathrm{L}$. The yield of 1,3-PD to glycerol when glucose, xylose, and arabinose were co-utilized with glycerol, increased by $28 \%(0.86 \mathrm{~mol} / \mathrm{mol}), 19 \%(0.80 \mathrm{~mol} / \mathrm{mol})$, respectively $18 \%(0.79 \mathrm{~mol} / \mathrm{mol})$. Therefore, lignocellulosic hydrolysates such as glucose, xylose, and arabinose could be considered as supplement resources in glycerol fermentation in order to increase the 1,3-PD production yields [20]. 
Nakas et al. [38] obtained $5 \mathrm{~g} / \mathrm{L}$ of 1,3-PD besides ethanol and butanol from $49 \mathrm{~g} / \mathrm{L}$ glycerol using the strain of Clostridium pasteurianum [38].

\section{CITROBACTER's 1,3-PD production}

Citrobacter freundii seems to be another promising organism for 1,3-PD production among Enterobacteriaceae. Casali et al. [39] compared the 1,3-PD producing potential of Citrobacter freundii strain DSM 15979, with Pantoea agglomerans DSM 30077, from crude glycerol as carbon source. The optimal quantity of raw glycerol which gave the highest 1,3-PD productivity, was about $40 \mathrm{~g} / \mathrm{L}$ at an average concentration of $20-60 \mathrm{~g} / \mathrm{L}$ used in preliminary studies. The final 1,3-PD concentration obtained using C. freundii was $12.92 \mathrm{~g} / \mathrm{L}$, while $6.14 \mathrm{~g} / \mathrm{L}$ was obtained for P. agglomerans. Both mentioned strains were able to accrue on crude glycerol leading to an accumulation of 1,3-PD in the cultural broths. From this report it can be observed that even if $P$. agglomerans is a novel bacterium in the field of CG conversion to 1,3-PD and it is not well investigated yet, it appears as a promising strain with appropriate yields to the 1,3-PD production [39].

Boenigk et al. [40] studied the process of glycerol conversion to 1,3-propanediol by Citrobacter freundii DSM 30040. The process was optimized in single- and twostage continuous cultures. The production of 1,3-PD was increased under glycerol limitation and elevated with the dilution rate (D) of $3.7 \mathrm{~g} / \mathrm{L} / \mathrm{h}$. The optimal conditions for the two-stage fermentation process were as follows: (a) first stage-glycerol limitation at $250 \mathrm{mM}, \mathrm{pH} 7.2$, $\mathrm{D}=0.1 \mathrm{~h}^{-1}, 31^{\circ} \mathrm{C}$; (b) second stage-additional glycerol, $\mathrm{pH}$ 6.6, $\mathrm{D}=0.05 \mathrm{~h}^{-1}, 28^{\circ} \mathrm{C}$. In these terms, the final concentration of 1,3-PD was $545 \mathrm{mM}$, and the concentration of consumed glycerol were $875 \mathrm{mM}$. The average productivity of $1,3-\mathrm{PD}$ recorded $1.38 \mathrm{~g} / \mathrm{L} / \mathrm{h}$. In order to gain a continuous productivity of 1,3-PD by conversion of glycerol, Boenigk et al. [40] mentioned that a growth limitation by nitrogen source or by phosphate could be helpful. This might enable glycerol to be present excessively in the medium and achieve maximum values of 1,3-PD concentrations. Taking into account these growth limitations, $2.9 \mathrm{mM}$ of ammonium or $0.75 \mathrm{mM}$ of phosphate in a medium culture supplemented with $0.02 \%$ yeast extract, C. freundii DSM 30040 grew to an optical density $\left(\mathrm{OD}_{578}\right)$ of 1.3. In contraposition to batch cultures, cells were extended and occurred in chains. In this case, cells were not highly productive in formation of 1,3-propanediol, and the specific activities of the responsible enzymes, like glycerol dehydratase and 1,3-propanediol dehydrogenase, were very low (data not shown) [40].

Metsoviti et al. [41] investigated the isolated Citrobacter freundii strain FMCC-B 294 (VK-19) for its potential of converting the biodiesel-derived glycerol into 1,3-propanediol. Their study demonstrated that raw glycerol used as a nutrient substrate was very effective for both C. freundii growth and 1,3-PD production. At the same time, their study proved that batch fermentations conducted in non-sterile conditions do not influence considerably the final concentration of 1,3-propanediol. In this regard, the research group obtained $68.1 \mathrm{~g} / \mathrm{L}$ of $1,3-$ PD with an yield of consumed glycerol of $0.40 \mathrm{~g} / \mathrm{g}$ and a volumetric productivity of $0.79 \mathrm{~g} / \mathrm{L} / \mathrm{h}$ during a sterile fed-batch fermentation, while $66.3 \mathrm{~g} / \mathrm{L}$ of $1,3-\mathrm{PD}$ were obtained from $176 \mathrm{~g} / \mathrm{L}$ of raw glycerol, performing nonsterilized fed-batch process. From this research it can be concluded that Citrobacter freundii strain FMCC-B 294 can grow and can convert efficiently biodiesel derivedglycerol into 1,3-propanediol in non-sterile conditions [41].

\section{Novel strains and mutants}

New strains have been modified in order to obtain a higher production of 1,3-propanediol. For example, Hartlep et al. [42] obtained glycerol using yeast named Pichia farinosa or an E. coli genetically modified strain, whereupon glycerol was converted to 1,3-PD by $K$. pneumoniae, and the overall yield was about $0.17 \mathrm{~g} / \mathrm{g}$ [42] Further advance has been performed by DuPont and Genencor Company. They employed a genetically modified bacteria using enzymes from strains as Saccharomyces and Klebsiella combined in one strain of E. coli $\mathrm{K} 12$, which transforms glucose directly to 1,3-PD with a final concentration of $130 \mathrm{~g} / \mathrm{L}$, but only with a low yield of $0.34 \mathrm{~mol} / \mathrm{mol}$ [43].

Even the utilization of crude glycerol during fermentation process gives some advantages in relation to the use of pure glycerol, there are few reports on the potential use of crude glycerol as a biodiesel by-product for the production of 1,3-propanediol. Most of them are conducted using pure glycerol as a sole carbon source [30].

In terms of 1,3-PD production, a novel strain has been investigated, namely Shimwellia blattae ATCC 33430. In a $2 \mathrm{~L}$ bioreactor, Rodriguez et al. [44] tested different concentrations of raw glycerol (between 20 and $70 \mathrm{~g} / \mathrm{L}$ ), during 6 experiments repeated three times. The best results were obtained for $29.5 \mathrm{~g} / \mathrm{L}$ of CG, representing a 1,3-PD concentration of $13.6 \mathrm{~g} / \mathrm{L}$, a yield of $0.49 \mathrm{~g} / \mathrm{g}$ and a productivity rate of $1.36 \mathrm{~g} / \mathrm{L} / \mathrm{h}$. The metabolic carbon flux switched to the oxidative pathway (to lactic acid and ethanol synthesis) when the initial concentration of glycerol was more elevated than $47.4 \mathrm{~g} / \mathrm{L}$ [44].

Strains from genus Lactobacillus have been found to produce significant amounts of 1,3-PD. Pflügl et al. [45] evaluated the capability of Lactobacillus diolivorans DSM 14421 to develop on glycerol as a nutrient source and to 
produce 1,3-propanediol. Concentrations of $41.7 \mathrm{~g} / \mathrm{L}$ for 1,3-PD were obtained in batch cultivation, while $73.7 \mathrm{~g} / \mathrm{L}$ were obtained in fed-batch cultivation when glycerol was co-fermented with glucose. Same authors suggest that vitamin B12 added as supplement to the culture medium has increased the production of 1,3-PD to a final concentration of $84.5 \mathrm{~g} / \mathrm{L}$ [45].

In Table 1 are mentioned several strains producing 1,3PD using crude or pure glycerol as sole carbon source.

\section{1,3-PD purification}

Considering the fact that 1,3-propanediol is a monomer obtained through fermentation process in passably low quantities, there is a demand for purification in order to gain a clear final product. Therefore, a series of separation techniques have been developed. According to the literature, there are three main steps in the purification process of 1,3-PD, and these are as follows: first of all, there is a removal of biomass (proteins and cells) through flocculation, membrane filtration, and high-speed centrifugation; second, there is a concentration of 1,3-PD through extraction, electrodialysis, and absorption; and third, there is a refining of high-purity 1,3-PD through vacuum distillation or distillation under reduced pressure [46].

Several studies reveal that there exist other methods for 1,3-PD purification. For example, Li et al. [47] reported that they recovered more than $95 \%$ of $1,3-\mathrm{PD}$ by using an aqueous two-phase system for extraction. Anyway, this procedure seems not to give a high purity of the end product [46]. Anggraini et al. [48] separated the fermentation products from other compounds beside 1,3-PD by

Table 1 The concentrations and yields of 1,3-PD obtained from crude and pure glycerol by various strains

\begin{tabular}{|c|c|c|c|c|c|c|}
\hline Strain & Carbon source & Fermentation type & $\begin{array}{l}\text { 1,3-PD concentra- } \\
\text { tion (g/L) }\end{array}$ & $\begin{array}{l}\text { 1,3-PD yield (mol/ } \\
\text { mol) }\end{array}$ & $\begin{array}{l}\text { 1,3-PD productivity } \\
\text { (g/L/h) }\end{array}$ & References \\
\hline $\begin{array}{l}\text { Klebsiella pneumoniae } \\
\text { DSM } 2026\end{array}$ & Crude glycerol & $\begin{array}{l}\text { Combined bio- } \\
\text { process }\end{array}$ & 61.1 & 0.51 & 2.0 & {$[6]$} \\
\hline $\begin{array}{l}\text { Klebsiella pneumoniae } \\
\text { DSM } 2026\end{array}$ & Pure glycerol & Batch, fed-batch & $35.2-48.5$ & 0.721 & $4.9-8.8$ & [26] \\
\hline $\begin{array}{l}\text { Klebsiella pneumoniae } \\
\mathrm{BLh}^{-1}\end{array}$ & Crude glycerol & Batch & 19.9 & 0.72 & - & [30] \\
\hline $\begin{array}{l}\text { Klebsiella pneumoniae } \\
\text { GLC29 }\end{array}$ & Pure glycerol & Batch & 20.4 & 0.51 & 2.92 & [31] \\
\hline Klebsiella oxytoca & Crude glycerol & Batch, fed-batch & - & $0.41-0.53$ & $0.63-0.83$ & {$[1]$} \\
\hline $\begin{array}{l}\text { Clostridium butyricum } \\
\text { F2b }\end{array}$ & Crude glycerol & Batch & 47.1 & - & - & [32] \\
\hline Clostridium IK124 & Crude glycerol & Fed-batch & 87 & 65 & 2.2 & [33] \\
\hline $\begin{array}{l}\text { Clostridium butyricum } \\
\text { VPI } 1718\end{array}$ & Crude/pure glycerol & Batch & 14.1 & 1.08 & 1.41 & [34] \\
\hline $\begin{array}{l}\text { Clostridium butyricum } \\
\text { VPI } 1718\end{array}$ & Crude glycerol & Fed-batch & 69.7 & 0.55 & 1.87 & {$[35]$} \\
\hline $\begin{array}{l}\text { Clostridium butyricum } \\
\text { AKR102a }\end{array}$ & Crude/pure glycerol & Fed-batch & $76.2 / 93.7$ & $0.622 / 0.632$ & $2.3 / 3.3$ & [37] \\
\hline $\begin{array}{l}\text { Clostridium diolis DSM } \\
15410\end{array}$ & Pure glycerol & Batch & 14.7 & 0.86 & 1.1 & [20] \\
\hline $\begin{array}{l}\text { Clostridium pasteuri- } \\
\text { anum }\end{array}$ & Crude glycerol & Batch & 5 & - & - & [38] \\
\hline $\begin{array}{l}\text { Citrobacter freundii } \\
\text { DSM } 15979\end{array}$ & Crude glycerol & Batch & 12.92 & - & - & [39] \\
\hline $\begin{array}{l}\text { Citrobacter freundii } \\
\text { DSM } 30040\end{array}$ & Pure glycerol & Batch & 60 & - & 1.38 & {$[40]$} \\
\hline $\begin{array}{l}\text { Citrobacter freundii } \\
\text { FMCC-B } 294\end{array}$ & Crude glycerol & Batch & 68.1 & 0.4 & 0.79 & [41] \\
\hline $\begin{array}{l}\text { Pantoea agglomerans } \\
\text { DSM } 30077\end{array}$ & Crude glycerol & Batch & 6.14 & - & - & [39] \\
\hline E. coli K12 & Pure glycerol & Fed-batch & 130 & 0.53 & 2.0 & [43] \\
\hline $\begin{array}{l}\text { Lactobacillus dio- } \\
\text { livorans DSM } 14421\end{array}$ & Pure glycerol & Fed-batch & 85.4 & 0.57 & 0.85 & [45] \\
\hline $\begin{array}{l}\text { Shimwellia blattae } \\
\text { ATCC } 33430\end{array}$ & Crude glycerol & Batch & 13.6 & $0.49 \mathrm{~g} / \mathrm{g}$ & 1.36 & [44] \\
\hline
\end{tabular}


using the atmospheric distillation method, and they evaluated the purity of investigated product using The Gas Chromatography system (GC) [48]. High performance liquid chromatography (HPLC) is often used for concentration evaluation of separated products.

A successful commercialization of 1,3-propanediol from biological sources imposes an improvement of an efficient purification system. In these terms, a fermentation broth which contains a plurality of components, like residual glycerol, water, glucose, by-products (acetate, lactate, succinate, ethanol and 2,3-butanediol), macromolecules (proteins, polysaccharides and nucleic acid), salts and residual medium, makes the 1,3-PD downstream process separation quite difficult [49].

Methods of 1,3-PD purification have been analyzed by many researchers in previous studies. There can be mentioned a few examples of important procedures for 1,3PD recovery: reactive extraction, liquid-liquid extraction, evaporation, distillation, membrane filtration, pervaporation and ion exchange chromatography. In this regard, all these methods have some drawbacks or limitations [49, 50]. In the context of reactive extraction, Broekhuis et al. [51] attempted to convert the targeted product into a compound without hydroxyl groups and then recovered it through solvent extraction. They used formaldehyde or acetaldehyde in order to create dioxane derivatives of 1,3-propanediol and 1,2-propanediol [47, 51].

Malinowski [52] studied liquid-liquid extraction, a method which can be used straight to recover a targeted product from a dilute solution, in case that a proper solvent is found. In his study, with the aid of extraction screening program (ESP), Malinowski performed a solvent screening where aldehydes and aliphatic alcohols were selected. The fact that 1,3-PD distribution into extraction solvents showed relevant differences between the theoretical and experimental values, made the whole process unsatisfactory in developing a simple and efficient extraction procedure [52].

The conventional techniques such as evaporation and distillation used for the removal of water and for 1,3-PD purification, consume high energy and lead to a raised price of the targeted product [49]. In the case of the vacuum distillation based separation process, it can be mentioned that it consumes less energy, due to the decrease of the boiling points. Still, this technique used for the recovery and purification of 1,3-PD gives low yields because it makes broth very viscous, and leads to low evaporation efficiency [49].

Cation exchange resin of polystyrene sulfonate in the $\mathrm{Na}$ form was used by Hilaly and Binder [53] for a strong separation of 1,3-propanediol from other compounds. With the aid of a simulated moving bed apparatus and added water as an eluent for the feed material, the process was performed. In this regard, the original feed solution was diluted by ten times. The results were satisfactory, recording a yield of 1,3-PD higher than 95\%. Even though high purity and yields of 1,3-PD can be obtained, the selectivity and capacity of the resin seem to be very low, so the 1,3-PD solution must be diluted, not concentrated. This method consumes a lot of energy compared to the simple evaporation and distillation methods. Moreover, the chromatographic matrix had to be regenerated frequently due to the fact that the feed was not desalinated or deproteinized $[49,53]$.

The purification of 1,3-propanediol by using an ion exchange comprising a strong acidic cation exchange resin and a weak basic anion exchange resin, was used in the removal of anionic and cationic molecules by Adkesson et al. [54]. This process implies the ion exchange resin regeneration more frequently, because of great amounts of anionic and cationic molecules in fermentative broths $[49,54]$.

Wilkins and Lowe [55] tested a chromatography process in order to remove 1,3-propanediol, aiming to prevent the feedback inhibition of cell growth and product formation in the fermentation process $[49,55]$. Also, a liquid chromatography column packed with silica resin was evaluated for the separation of 1,3-PD from a 1,3-propanediol and 1,2-propanediol mixture after phase separation using ethyl acetate $[49,56]$.

Regarding the 1,3-PD purification, Saxena et al. [49] would particularly mention a novel technique based on their recent studies on purification of 1,3-PD from the fermentation broth. They separated the 1,3-PD in three main steps: proteins ejection, broth concentration, and 1,3-PD separation through chromatography. The mentioned method assumes relatively simple equipment and an easy maintenance compared to other available techniques. In Saxena's study, a cheaply available compound was used as compared to the expensive chitosan for protein removal, thereby reducing the cost of the procedure [49]. The broth concentration was achieved by the vacuum distillation method, and the concentrated broth was purified afterwards by chromatography. In their study Saxena et al. [49] proved that 1,3-PD can be recovered from the fermentation broth with this technique, which resulted in a yield of $98 \%$. It can be mentioned that their process is simple, efficient and fast, and it avoids the high price obstruction caused in the commercialization of 1,3 PD production [49].

\section{The bioconversion of glycerol to citric acid (CA)}

Citric acid is well-known industrial product and can be obtained primarily by fermentation. Because of its low toxicity compared with other acidulants, the citric acid is used to add a pleasant and astringent flavor to beverages 
and aliments [57]. In terms of biochemical properties, the citric acid, also named 2-hydroxy-propane-1,2,3tricarboxylic acid, was first described as a compound obtained from citrus plants and known as an intermediate of the tricarboxylic acid (TCA) cycle (Scheme 4). CA combines an enjoyable taste with an impressive palatability, so it becomes a ubiquitous food additive [58]. CA is also applied as an additive in functional detergents, in pharmaceuticals, and cosmetics. With a global annual production over 1.7 million tons, $\mathrm{CA}$ is noticed to be the first among the organic acids synthesized by bacteria. Multiple microorganisms, mainly Yarrowia lipolytica and Aspergillus niger are used to ferment various nutrient sources in order to obtain high yields of CA. As an example, Y. lipolytica can grow on a variety of carbon sources, like sugars, plant oils, alkanes, hydrolysates, ethanol, and glycerol under nutrient-limited conditions, and is competent to produce CA [57, 59-61].

The chemical conversion of glycerol can be interpreted in three manners: (a) by oxidation and reduction of glycerol into other 3-carbon compounds; (b) by synthesis of higher carbon compounds with glycerol and other substrates; (c) by industrial combustion [23]. These are traditional chemical catalytic methods, and often involve expensive metal catalysts, toxic intermediate compounds, and low conversion rates. Furthermore, it is very difficult to burn glycerol productively because of its high viscosity, low energy density, high auto-ignition temperature, and potential emission problems. In this context, glycerol conversion using microorganisms is a viable option compared to the direct application and chemical transformation, and in this way, certain drawbacks such as low product specificity, intensive pretreatment requirements, and high energy intake (pressure/temperature), can be avoided [23].

The industrial citric acid production can be carried also, in three different ways: by submerged fermentation, surface fermentation and solid-state fermentation [57]. All of the mentioned methods demand excellent raw material and a proper production fermenter for a direct strain inoculation. Soccol et al. [57] underline that CA accumulation is strongly influenced by the type and the concentration of the carbon source [57]. The carbohydrates are rapidly consumed by microorganisms and they are essential for a better production of citric acid. As examples of the more easily metabolized carbohydrates, sucrose is the most favored carbon source, followed by glucose, fructose and galactose [57].

During the glycerol fermentation by specific strains, citric acid synthesis implies depletion of nitrogen source from the cultivation media $[32,64]$. The nitrogen exhaustion leads to a sudden decrease of intracellular AMP concentration, due to its separation caused by
AMP-desaminase. Thereby, NAPD ${ }^{+}$-isocitrate dehydrogenase (the enzyme which is responsible for iso-citric change to a-ketoglutaric acid) loses its activity due to the fact that it is allosterically activated by the intracellular AMP, phenomenon which leads to the CA accumulation within the mitochondria [64]. If the citric acid concentration exceeds the critical value, $\mathrm{CA}$ is secreted into the cytoplasmic matrix. There are some oleaginous yeasts which are able to dissociate the cytoplasmic CA into acetyl-CoA and oxaloacetate by using ATP-citrate lyase $(\mathrm{ACL})$, an enzyme responsible for lipid accumulation process. Acetyl-CoA is subjected next to a quasi-reversed $\beta$-oxidation reaction to cellular fatty acids [65]. That is to say, citric acid is used by oleaginous microorganisms as an acetyl-CoA donor in the anabolic pathway of fatty acids synthesis [64]. On the contrary, non-oleaginous microorganisms excrete the accumulated citric acid into the culture broth $[63,64]$.

Several synthetic routes have been developed by using different starting materials, but it is mentioned that chemical ways have been proved to be uncompetitive with the fermentation processes, mainly because the starting materials are much more expensive than the final product $[62,66]$.

\section{YARROWIA's citric acid production}

The increased yield of organic acid (citric acid) production by using crude glycerol has primarily been reported in strains of the Yarrowia lipolytica yeast. This microorganism was considered to be the most productive strain for citric acid converted from crude glycerol $[8,32,60]$. The cultivation of natural strains of Y. lipolytica on both crude glycerol from biodiesel production, and pure glycerol gave similar results regarding the CA yields. $Y$. lipolytica poses the ability to produce other valuable compounds, like biosurfactants, by fermentation of crude glycerol as sole carbon source [8].

In biotechnological processes, the biosynthesis of citric acid is performed in batch, fed-batch, as well as in repeated-batch cultures, occasionally with cell recycle and medium replacement. In their study, Rywińska et al. [60] investigated the yield and CA production of Y. lipolytica Wratislavia AWG7, which is an acetate-negative mutant with a smooth colony phenotype. The process was conducted under steady-state conditions, where the rising of the dilution rate was simultaneously performed by the reduction of CA concentration ranging from 86.5 to $51.2 \mathrm{~g} / \mathrm{L}$. Similar increase was recorded for the volumetric rate (from 0.78 to $1.59 \mathrm{~g} / \mathrm{L} / \mathrm{h}$ ) and the specific rate (from 0.05 to $0.18 \mathrm{~g} / \mathrm{g} / \mathrm{h}$ ) of citric acid production. The production process yield varied from 0.59 to $0.67 \mathrm{~g} / \mathrm{g}$ [60]. 


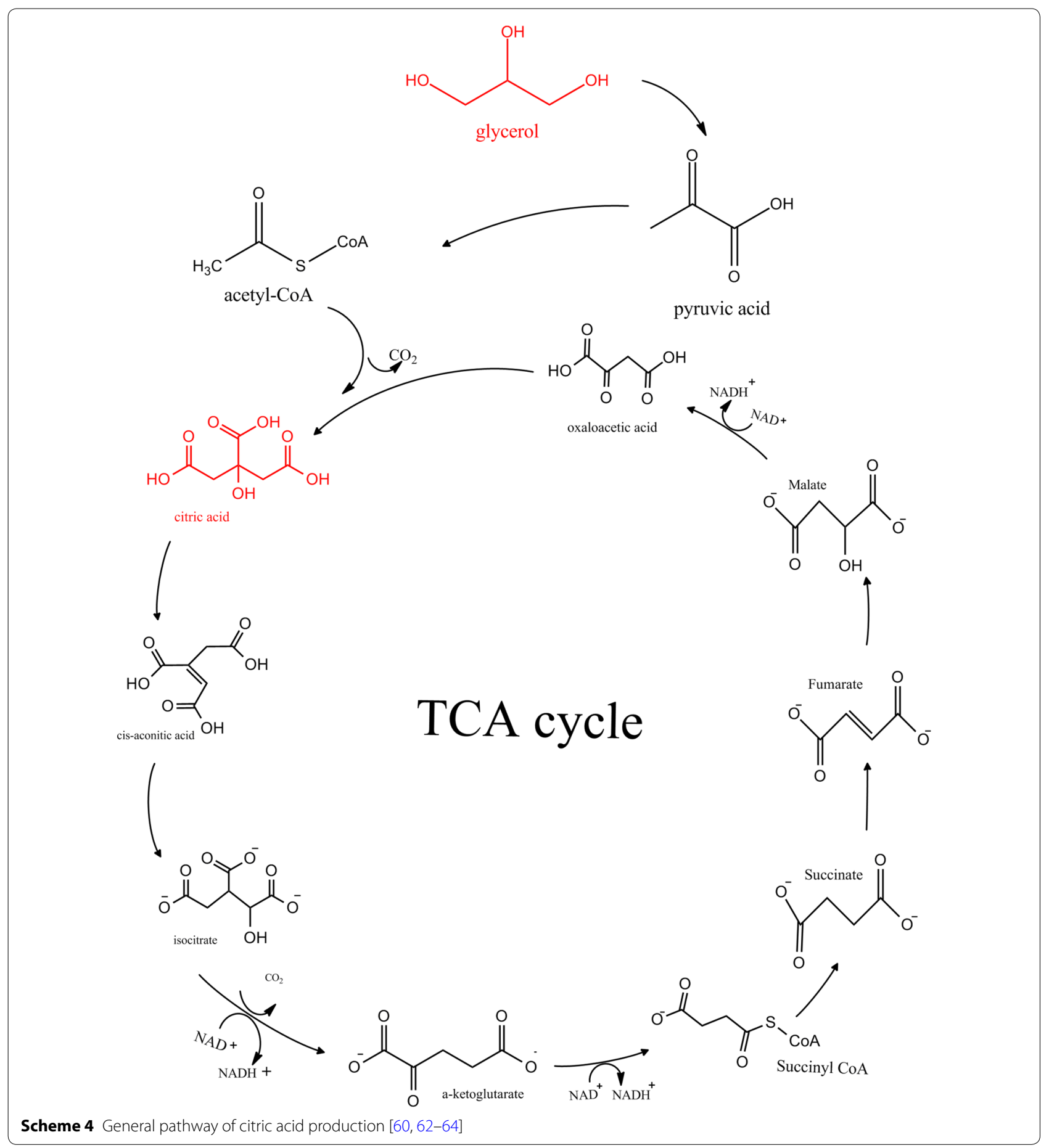

In another research conducted by Rywińska et al. [67], one wild strain (Y. lipolytica A-101) was compared with three acetate-negative mutants of $Y$. lipolytica (Wratislavia 1.31, Wratislavia AWG7, and Wratislavia K1) regarding their capacity to produce CA from glucose and pure or raw glycerol in batch fermentations. The carbon source was used both as a single substrate and as mixtures of glucose and pure or raw biodiesel-derived glycerol. The final results pointed that the highest amount of CA were produced by A-101 (concentration: $82.2 \mathrm{~g} / \mathrm{L}$; yield: $0.45-0.52 \mathrm{~g} / \mathrm{g}$; productivity: $0.71-0.83 \mathrm{~g} / \mathrm{L} / \mathrm{h}$ ), Wratislavia AWG7 (76.6 g/L; 0.46-0.48 g/g; 0.76-0.81 g/L/h) 
and Wratislavia 1.31 (71 g/L; 0.45-0.46 g/g; 0.57$0.69 \mathrm{~g} / \mathrm{L} / \mathrm{h}$ ) strains from media containing a mixture of raw glycerol and glucose. On the other hand, Wratislavia K1 strain produced good quantities of erythritol (from 18.1 to $30 \mathrm{~g} / \mathrm{L}$ ) throughout the entire cultivation process, and lower quantities of citric acid (concentration: $36.8-53.3 \mathrm{~g} / \mathrm{L}$; yield: $0.27-0.3 \mathrm{~g} / \mathrm{g}$; productivity: $0.51-$ $0.64 \mathrm{~g} / \mathrm{L} / \mathrm{h})[67]$.

Strains like $Y$. lipolytica Wratislavia 1.31 and $Y$. lipolytica Wratislavia AWG7 were tested in fed-batch systems using different elevated concentrations of raw glycerol (200 and $300 \mathrm{~g} / \mathrm{L}$ ) as substrate for producing citric acid. For Wratislavia 1.31 strain, when $200 \mathrm{~g} / \mathrm{L}$ of substrate were used, $126 \mathrm{~g} / \mathrm{L}$ of citric acid were obtained within $120 \mathrm{~h}$ of fermentation, recording a yield of $0.63 \mathrm{~g} / \mathrm{g}$ and a productivity of $1.05 \mathrm{~g} / \mathrm{L} / \mathrm{h}$. For Wratislavia AWG7, when $200 \mathrm{~g} / \mathrm{L}$ of substrate were used, $113.5 \mathrm{~g} / \mathrm{L}$ of citric acid were produced within $121 \mathrm{~h}$ of fermentation (yield: $0.57 \mathrm{~g} / \mathrm{g}$; productivity: $0.94 \mathrm{~g} / \mathrm{L} / \mathrm{h}$ ). When the total glycerol concentration was raised up to $300 \mathrm{~g} / \mathrm{L}$, with Wratislavia 1.31 strain it were achieved $155.2 \mathrm{~g} / \mathrm{L}$ of citric acid (yield: $0.58 \mathrm{~g} / \mathrm{g}$; productivity: $0.6 \mathrm{~g} / \mathrm{L} / \mathrm{h}$ ) and $157.5 \mathrm{~g} / \mathrm{L}$ with Wratislavia AWG7 (yield: $0.55 \mathrm{~g} / \mathrm{g}$; productivity: $0.6 \mathrm{~g} / \mathrm{L} / \mathrm{h})[68]$.

Rymowicz et al. [69] performed a batch fermentation in order to evaluate and compare the CA production of the named acetate-negative mutants of $Y$. lipolytica (K-1, AWG-7, 1.31). The principal source of carbon was crude glycerol (with an initial concentration about $200 \mathrm{~g} / \mathrm{dm}^{3}$ ) obtained from biodiesel manufacturing, where rapeseed oil was used as raw material. At the end of the process, $Y$. lipolytica strain 1.31 gave best CA productivity, namely $124.5 \mathrm{~g} / \mathrm{dm}^{3}$ of citric acid, with a yield of $0.62 \mathrm{~g} / \mathrm{g}$. Moderate values were registered for both $Y$. lipolytica $\mathrm{K}-1$ and $Y$. lipolytica AWG-7 (75.7 g/ $\mathrm{dm}^{3}, \mathrm{y}=0.40 \mathrm{~g} / \mathrm{g}$ for $\mathrm{K}-1$ strain, and $88.1 \mathrm{~g} / \mathrm{dm}^{3}, \mathrm{y}=0.46 \mathrm{~g} / \mathrm{g}$ for AWG-7) [69].

Another study conducted in 2010 by Rymowicz et al. [70] presents the CA producing potential of Yarrowia lipolytica A-101-1.22. This strain produced citric acid in concentration of $112 \mathrm{~g} / \mathrm{L}$, with a yield of $0.6 \mathrm{~g}$ of CA per $\mathrm{g}$ of consumed glycerol, and a productivity of $0.71 \mathrm{~g} / \mathrm{L} / \mathrm{h}$ during batch fermentation by using raw glycerol [70].

Rywińska and Rymowicz [71] obtained similar results $(154 \mathrm{~g} / \mathrm{L}$ of citric acid; a yield of $0.78 \mathrm{~g} / \mathrm{g}$ and a productivity of $1.05 \mathrm{~g} / \mathrm{L} / \mathrm{h}$ ) with $Y$. lipolytica Wratislavia AWG-7 when raw glycerol was fed in long-term repeated-batch cultures. They also investigated the culture activity which remained stable for more than $1650 \mathrm{~h}$ (16 cycles of the repeated-batch bioreactors) [71].

Kamzolova et al. [72] examined the potential of acids formation of 66 yeast strains from different genera, like Candida, Pichia, Saccharomyces, Torulopsis and Yarrowia. Among them, the mutant strain of Yarrowia lipolytica N15 was selected due to its ability to produce citric acid in high amounts. Under optimal conditions, the mutant $Y$. lipolytica $\mathrm{N} 15$ produced up to $98 \mathrm{~g} / \mathrm{L}$ of CA (yield: $0.70 \mathrm{~g} / \mathrm{g}$; productivity: $1.14 \mathrm{~g} / \mathrm{L} / \mathrm{h}$ ) when it is grown on medium containing pure glycerol, and $71 \mathrm{~g} / \mathrm{L}$ of CA (yield: $0.9 \mathrm{~g} / \mathrm{g}$; productivity: $0.89 \mathrm{~g} / \mathrm{L} / \mathrm{h}$ ) when it is grown on medium with glycerol-containing waste from biodiesel industry [72].

Yarrowia lipolytica strain NG40/UV7 was found to produce $115 \mathrm{~g} / \mathrm{L}$ of citric acid in fed-batch fermentation when pure glycerol was added in the medium from 20 to $80 \mathrm{~g} / \mathrm{L}$. During the fermentation process containing raw glycerol (under the same conditions), $112 \mathrm{~g} / \mathrm{L}$ of citric acid were produced [73]. In another trial, the mutant strain NG40/UV7 was tested during $192 \mathrm{~h}$ of fermentation when the culture media presented $20 \mathrm{~g} / \mathrm{L}$ of glycerolcontaining waste and $4 \mathrm{~g} / \mathrm{L}$ of fatty acids [9]. The final concentration of synthesized citric acid was $122.2 \mathrm{~g} / \mathrm{L}$ with a yield of $0.95 \mathrm{~g} / \mathrm{g}$ and a productivity of $0.99 \mathrm{~g} / \mathrm{L} / \mathrm{h}$ [9].

Among the yeast strains, Yarrowia lipolytica NRRL YB-423 is shown by Levinson et al. [61] to produce the highest yield (54\%) of citric acid (21.6 g/L CA from $40 \mathrm{~g} / \mathrm{L}$ glycerol) [61]. These values were obtained by strain cultivation on pure glycerol. Also, crude glycerol was tested for citric acid production by Y. lipolytica NRRL YB-423, and the CA yield obtained with this substrate was $55.7 \%$ at the time of harvesting, and $94 \mathrm{mg} / \mathrm{L} / \mathrm{h}$ was the rate of production over a period of 10-days of incubation. In this context, the yield and the production rate with crude glycerol are comparable to data obtained with pure glycerol used as a nutrient substrate. There have been reported similar CA yields based on raw glycerol resulted from a biodiesel production for $Y$. lipolytica ACA-DC 50109 strain $[32,61]$.

Papanikolaou and colleagues suggest that Yarrowia lipolytica strain ACADC 50109 [LGAM S(7)1] presented a moderate accumulation of citric acid in the medium reaction when they were cultivated on crude glycerol as substrate in nitrogen limited flask cultures [32]. Citric acid was produced after the exhaustion of nitrogen from the medium, resulting in a final quantity of $62.5 \mathrm{~g} / \mathrm{L}$ and the yield on glycerol consumed was $0.56 \mathrm{~g} / \mathrm{g}$ [32]. The very same strain $Y$. lipolytica ACADC 50109 produced around $50-55 \mathrm{~g} / \mathrm{L}$ of citric acid on glucose in mono- or in dual substrate (productivity: $0.6 \mathrm{~g} / \mathrm{L} / \mathrm{h}$ in both cultures), under optimized conditions with pO2 control [74]. During the same trial, when glycerol was used in mono-substrate culture, $18 \mathrm{~g} / \mathrm{L}$ of citric acid was obtained with a productivity of $0.2 \mathrm{~g} / \mathrm{L} / \mathrm{h}$ [74].

During another experiment, Papanikolaou et al. [63] examined the CA producing potential and the lipid accumulation in Yarrowia lipolytica strain after the 
inactivation of the 2-methyl-citrate dehydratase. The mutant Y. lipolytica JMY1203 was tested in nitrogen limited conditions and it produced up to $57.7 \mathrm{~g} / \mathrm{L}$ of total citrate, with a glycerol to citrate yield of $0.92 \mathrm{~g} / \mathrm{g}$, and a productivity of $0.17 \mathrm{~g} / \mathrm{L} / \mathrm{h}$. The fermentation process started from an initial substrate (crude glycerol or glucose) of $40 \mathrm{~g} / \mathrm{L}$ [63].

Imandi et al. [16] evaluated the amount of citric acid production through a Doehlert experimental design, with the aid of the Yarrowia lipolytica microorganism, strain NCIM 3589. The maximum CA production was $77.399 \mathrm{~g} / \mathrm{L}$, resulting from $54.408 \mathrm{~g} / \mathrm{L}$ of crude glycerol [16].

In another research paper, Papanikolaou et al. [75] suggest that $Y$. lipolytica strain LGAM S(7)1 gives a good biochemical response on raw glycerol as growth condition. At the end, relatively increased amounts of citric acid were produced, like $12 \mathrm{~g} / \mathrm{L}$, with a yield $\mathrm{Y}_{\mathrm{Cit} / \mathrm{Glol}}$ of $0.38 \mathrm{~g} / \mathrm{g}$ and a specific CA production rate of $0.04 \mathrm{~g} / \mathrm{g} / \mathrm{h}$. Growth and the parameters of citric acid production have been noticed to be comparable to those obtained from glucose, while glycerol intake was higher than intake of glucose, when Y. lipolytica is used [75].

Da Silva et al. [76] studied the bioconversion of crude glycerol resulted from biodiesel industry, into citric acid using Y. lipolytica IMUFRJ 50682 strain. They tested different initial concentrations of glycerol as nutrient substrate and added ammonium sulfate to the fermentation process. The substrate they used was obtained through the transesterification reaction of soybean oil with ethanol, and catalyzed by $\mathrm{NaOH}$. Final products were analysed by high performance liquid chromatography (HPLC). At the end of the batch fermentation they observed that the citric acid production was about $12.94 \mathrm{~g} / \mathrm{L}$, in $160 \mathrm{~h}$ of fermentation of $45 \mathrm{~g} / \mathrm{L}$ of glycerol. The use of ammonium sulfate during batch fermentation led to an increase of isocitric acid and a decrease of CA production, according to HPLC analysis. In the tests where ammonium sulfate was added $(0.7 \mathrm{~g} / \mathrm{L})$ in order to determine the influence of nitrogen as a supplement source for citric acid production, the results pointed that the addition of ammonium sulfate to the culture medium leads to the metabolic path for the production of isocitric acid. In $93 \mathrm{~h}$ of fermentation it were obtained $16.79 \mathrm{~g} / \mathrm{L}$ of isocitric acid and only $1.46 \mathrm{~g} / \mathrm{L}$ citric acid when nitrogen was added. The authors concluded that a reduction in citric acid production is observed when nitrogen source is added to the fermentation process [76].

In the context of Yarrowia's CA productivity, André et al. [77] tested the conversion potential of crude glycerol into citric acid by three different Yarrowia lipolytica strains (LFMB 19, LFMB 20 and ACA-YC 5033). In their submerged shake-flask experiments they used an initial concentration of $30 \mathrm{~g} / \mathrm{L}$ of raw glycerol as a sole carbon substrate, leading to a satisfactory bacteria growth, a complete glycerol intake, and a good citric acid secretion. The authors suggest that for the strains Y. lipolytica LFMB 19 and Y. lipolytica LFMB 20, the principal metabolic product synthesized was mannitol (with a maximum concentration of $6.0 \mathrm{~g} / \mathrm{L}$, yield $0.20-0.26 \mathrm{~g} / \mathrm{g}$ of CG consumed). These two strains recorded a low productivity of CA, such as $4.6 \mathrm{~g} / \mathrm{L}$ with a yield of $0.25 \mathrm{~g} / \mathrm{g}$ for LFMB 19 strain, and $3.2 \mathrm{~g} / \mathrm{L}$ with a yield of $0.13 \mathrm{~g} / \mathrm{g}$ for LFMB 20 strain. Opposite, the last named strain, Y. lipolytica ACA-YC 5033, registered simultaneously higher concentrations of both lipids and citric acid. It is noted that CA concentrations have increased with the increment of glycerol quantity, and the maximum total citric acid production was $50.1 \mathrm{~g} / \mathrm{L}$ (yield $0.44 \mathrm{~g} / \mathrm{g}$ of CG). From this report it can be observed that waste glycerol represents a proper carbon source for strains like Y. lipolytica [77].

Yarrowia lipolytica LFMB 20 growth was also tested by Papanikolaou et al. [13] on media containing high quantity of glycerol or high quantity of glucose. LFMB 20 produced citrate around $58 \mathrm{~g} / \mathrm{L}$ in a culture with highglucose intake, while on high-glycerol media around $42 \mathrm{~g} / \mathrm{L}$ of citrate was produced, and about $18 \mathrm{~g} / \mathrm{L}$ of mannitol. In batch cultures, when a mixture of glucose and industrial glycerol was used, citrate was obtained in a concentration of $53.4 \mathrm{~g} / \mathrm{L}$ [13].

\section{ASPERGILLUS's citric acid production}

Even though such strain is well investigated for the production of citric acid, few reports are presented for its capacity to convert glycerol into CA. Generally, citric acid is created by submerged microbial fermentation on molasses using Aspergillus niger [2]. Even though Aspergillus niger is considered the main producer of CA by fermentation of different organic carbon sources, it seems that crude glycerol does not represent a good substrate for the production of citric acid. In this respect, the studies have been led on yeast strains (e.g. Yarrowia lipolytica) as an appropriate substitution. This can be explained by their resistance to high substrate concentrations and increased tolerance to impurities, allowing the use of low-quality substrates [8].

$\mathrm{Xu}$ et al. [78] investigated the effect of concentration and type of the carbon source on accumulation of citric acid in a batch fermenter induced by Aspergillus niger. In their report they presented a list of carbon sources (sucrose, maltose, fructose, glucose, glycerol, ethanol, succinate) tested for a high production of CA. The production of citric acid on glycerol was $17 \mathrm{mg} / \mathrm{mL}$, starting from an initial carbon source concentration of $14 \%$, while the results on maltose were obviously higher $(49 \mathrm{mg} / \mathrm{mL})$. Their work demonstrates that the concentration and the 
type of the carbohydrate source have a significant impact on the production of citric acid by A. niger [78] (Table 2).

\section{Conclusions and outlook}

Crude glycerol is a biodegradable, safe, cheap, and reusable source of carbon, and presents a proper raw material for value-added compounds production. There is a considerable industrial interest in 1,3-propanediol and in citric acid production based on microbial fermentations, as it appears to be in competition with traditional technologies utilized to obtain such products. 1,3-propanediol is a very useful chemical compound with a major impact in the industry of biodegradable plastics, with a variety of applications. Citric acid is a widely used compound in the food industry because of its properties (flavor, antioxidant properties, taste, and low toxicity). It is considered that crude glycerol may become a valuable raw material for the production of different bio-chemical products, which will generate an important economic impact.

From this review it can be observed that microorganisms from Enterobacteriaceae family (Klebsiella, Citrobacter, Lactobacillus) and microorganisms from Clostridiaceae family (Clostridium) can be considered as good producers of 1,3-propanediol using crude glycerol as nutrient source (K. pneumoniae DSM 2026-61.1 g/L; Cl. butyricum F2b-93.7 g/L; E. coli $\mathrm{K} 12-130 \mathrm{~g} / \mathrm{L} ; L$. diolivorans DSM 14421-84.5 g/L) [6, 37, 43, 45]. For citric acid production, raised values were registered for Yarrowia yeast, and specifically Yarrowia lipolytica strain Wratislavia AWG7 gave a concentration of citric acid production of $157.5 \mathrm{~g} / \mathrm{L}$ [68].

Waste glycerol from biodiesel industry can be considered an important raw material for future prospects, considering that it provides the carbon source for microbial

Table 2 The concentrations and yields of CA from converted glycerol by Yarrowia and Aspergillus strains

\begin{tabular}{|c|c|c|c|c|c|}
\hline Strain & Carbon source & CA concentration $(g / L)$ & CA yield $(g / g)$ & Productivity (g/L/h) & References \\
\hline \multirow[t]{3}{*}{ Y. lipolytica 1.31} & Crude glycerol & 124.5 & 0.62 & 0.88 & [69] \\
\hline & Pure/crude glycerol + glucose & 71 & $0.45-0.46$ & $0.57-0.69$ & [67] \\
\hline & Crude glycerol & $126-155$ & $0.58-0.63$ & $0.6-1.05$ & [68] \\
\hline \multirow[t]{4}{*}{ Y. lipolytica Wratislavia AWG7 } & Pure glycerol & $51.2-86.5$ & $0.59-0.67$ & $0.78-1.59$ & [60] \\
\hline & Pure/crude glycerol + glucose & 76.6 & $0.46-0.48$ & $0.76-0.81$ & [67] \\
\hline & Crude glycerol & $113.5-157.5$ & $0.55-0.57$ & $0.6-0.94$ & [68] \\
\hline & Crude glycerol & 154 & 0.78 & 1.05 & [71] \\
\hline \multirow[t]{2}{*}{ Y. lipolytica K-1 } & Pure glycerol & 75.7 & 0.40 & 0.81 & [69] \\
\hline & Pure/crude glycerol + glucose & $36.8-53.3$ & $0.27-0.3$ & $0.51-0.64$ & [67] \\
\hline Y. lipolytica A-101 & Pure/crude glycerol + glucose & 82.2 & $0.45-0.52$ & $0.71-0.83$ & [67] \\
\hline Y. lipolytica A-101-1.22 & Crude glycerol & 112 & 0.6 & 0.71 & [70] \\
\hline \multirow[t]{2}{*}{ Y. lipolytica N15 } & Pure glycerol & 98 & 0.70 & 1.14 & {$[72]$} \\
\hline & Crude glycerol & 71 & 0.9 & 0.89 & \\
\hline \multirow[t]{3}{*}{ Y. lipolytica NG40/UV7 } & Pure glycerol & 115 & 0.64 & 0.80 & [73]. \\
\hline & Crude glycerol & 112 & 0.9 & 0.82 & \\
\hline & Crude glycerol + fatty acids & 122.2 & 0.95 & 0.99 & [9] \\
\hline Y. lipolytica NRRL YB-423 & Pure glycerol & 21.6 & - & 0.94 & [61] \\
\hline \multirow[t]{3}{*}{ Y. lipolytica ACADC 50109} & Crude glycerol & 62.5 & 0.56 & 0.1 & [32] \\
\hline & Glucose & $50-55$ & 0.83 & 0.6 & {$[74]$} \\
\hline & Pure glycerol & 17.8 & 0.3 & 0.2 & \\
\hline Y. lipolytica JMY1203 & Crude glycerol/glucose & 57.7 & 0.92 & 0.17 & [63] \\
\hline Y. lipolytica NCIM 3589 & Crude glycerol & 77.39 & - & - & [16] \\
\hline Y. lipolytica LGAM S(7)1 & Crude glycerol & 12 & 0.38 & 0.4 & [75] \\
\hline Y. lipolytica IMUFRJ 50682 & Crude glycerol & 12.94 & - & - & [76] \\
\hline Y. lipolytica LFMB 19 & Crude glycerol & 4.6 & 0.25 & - & [77] \\
\hline \multirow[t]{4}{*}{ Y. lipolytica LFMB 20} & Crude glycerol & 3.2 & 0.13 & - & [77] \\
\hline & Crude glycerol & 42 & 0.39 & - & [13] \\
\hline & Glucose & 58 & 0.55 & - & \\
\hline & Glucose + crude glycerol & 53.4 & 0.41 & - & \\
\hline Y. lipolytica ACA-YC 5033 & Crude glycerol & 50.1 & 0.44 & - & {$[77]$} \\
\hline Aspergillus niger & Pure glycerol & 17 & - & - & [78] \\
\hline
\end{tabular}


growth. By recovering the waste glycerol from biofuels production and valuing it through bacterial fermentation in order to obtain value-added products, it has a positive economic and environmental impact.

\begin{abstract}
Abbreviations
1,3-PD: 1,3-propanediol; CA: citric acid; CG: crude glycerol; HLB: hydrophiliclipophilic profile; PTT: polytrimethylene terephthalate; PET: polyethylene terephthalate; PBS: polybutylene terephthalate; D: dilution rate; OD: optical density; GC: gas chromatography; HPLC: high performance liquid chromatography; ESP: extraction screening program; TCA: tricarboxylic acid cycle.
\end{abstract}

\section{Authors' contributions}

LM investigated the references and wrote the review; MT, AC and DV outlined and assembled the manuscript. All authors read and approved the final manuscript.

\section{Author details \\ 1 Department of Food Science, Faculty of Food Science and Technology, Institute of Life Sciences, University of Agricultural Sciences and Veterinary Medicine Cluj-Napoca, Calea Mănăstur 3-5, 400372 Cluj-Napoca, Romania. 2 Pathophysiology Department, "Iuliu Haţieganu" University of Medicine and Pharmacy, Cluj-Napoca, Romania.}

\section{Acknowledgements}

Not applicable.

\section{Competing interests}

The authors declare that they have no competing interests.

\section{Availability of data and materials}

Not applicable.

\section{Consent for publication}

Not applicable.

\section{Ethics approval and consent to participate}

This article does not contain any studies with human participants or animals performed by any of the authors.

\section{Funding}

This work was supported by the Competitiveness Operational Programme Priority Axis 1, Action 114, Project Type "Attracting high level personal from abroad" POC-A1-A1.1.4-E_2015 developed with the support of MCI (Acronym: ProGlyCom, Project ID: POC/ID P_37_637, 2016-2020).

\section{Publisher's Note}

Springer Nature remains neutral with regard to jurisdictional claims in published maps and institutional affiliations.

Received: 26 June 2017 Accepted: 1 November 2017

Published online: 06 November 2017

\section{References}

1. Garlapati VK, Shankar U, Budhiraja A. Bioconversion technologies of crude glycerol to value added industrial products. Biotechnol Rep (Amp). 2015;2(9):9-14.

2. Da Silva GP, Mack M, Contiero J. Glycerol: a promising and abundant carbon source for industrial microbiology. Biotechnol Adv. 2009;27:30-9.

3. Lee CS, Aroua MK, Daud WMAW, Cognet P, Pérès-Lucchese Y, Fabre PL, Reynes O, Latapie L. A review: conversion of bioglycerol into 1,3-propanediol via biological and chemical method. Renew Sust Energ Rev. 2015:42:963-72.

4. Drożdżyńska A, Leja K, Czaczyk K. Biotechnological production of 1,3-propanediol from crude glycerol. BioTechnologia. 2011;92(1):92-100
5. Leoneti AB, Aragão-Leoneti V, De Oliveira SVWB. Glycerol as a by-product of biodiesel production in Brazil: alternatives for the use of unrefined glycerol. Renew Energy. 2012;45:138-45.

6. Mu Y, Xiu Z-L, Zhang D-J. A combined bioprocess of biodiesel production by lipase with microbial production of 1,3-propanediol by Klebsiella pneumoniae. Biochem Eng J. 2008:40:537-41.

7. Pagliaro M, Rossi M. The future of glycerol: new uses of a versatile raw material. Chapter 1 Glycerol: properties and production. RSC Green Chemistry Book Series. 2008. p. 10-4.

8. Konstantinovié SS, Danilović BR, Cirié JT, llić SB, Savić DS, Veljkovié VB. Valorization of crude glycerol from biodiesel production. Chem Ind Chem Eng. 2016;22(4):461-89.

9. Morgunov IG, Kamzolova SV. Physiologo-biochemical characteristics of citrate-producing yeast Yarrowia lipolytica grown on glycerol-containing waste of biodiesel industry. Appl Microbiol Biotechnol. 2015;99:6443-50.

10. Hejna A, Kosmela P, Formela K, Piszczyk Ł, Haponiuk JT. Potential applications of crude glycerol in polymer technology-current state and perspectives. J Renew Sustain Energy. 2016;66:449-75.

11. Vodnar DC, Dulf FV, Pop OL, Socaciu C. L(+)-Lactic acid production by pellet-form Rhizopus oryzae NRRL 395 on biodiesel crude glycerol. Microb Cell Fact. 2013;12:92.

12. Chatzifragkou A, Makri A, Belka A, Bellou S, Mavrou M, Mastoridou M, Mystrioti P, Onjaro G, Aggelis G, Papanikolaou S. Biotechnological conversions of biodiesel derived waste glycerol by yeast and fungal species. Energy. 2011;36:1097-108

13. Papanikolaou S, Rontou M, Belka A, Athenaki M, Gardeli C, Mallouchos A, Kalantzi O, Koutinas AA, Kookos IK, Zeng AP, Aggelis G. Conversion of biodiesel-derived glycerol into biotechnological products of industrial significance by yeast and fungal strains. Eng Life Sci. 2017;17:262-81.

14. Kong PS, Aroua MK, Daud WMAW. Conversion of crude and pure glycerol into derivatives: a feasibility evaluation. J Renew Sustain Energy. 2016:63:533-55.

15. Kośmider A, Drożdżyńska A, Blaszka K, Leja K, Czaczyk K. Propionic acid production by Propionibacterium freudenreichii ssp. shermanii using industrial wastes: crude glycerol and whey lactose. Pol J Environ Stud. 2010;19(6):1249-53.

16. Imandi SB, Bandaru VVR, Somalanka R, Garapati HR. Optimization of medium constituents for the production of citric acid from byproduct glycerol using Doehlert experimental design. Enzyme Microb Tech. 2007:40:1367-72

17. Fan X, Burton R, Zhou Y. Glycerol (byproduct of biodiesel production) as a source for fuels and chemicals_-mini review. TOEFJ. 2010;3:17-22.

18. Igari S, Mori S, Takikawa Y. Effects of molecular structure of aliphatic diols and polyalkylene glycol as lubricants on the wear of aluminum. Wear. 2000:244:180-4.

19. Biebl H, Menzel K, Zeng AP, Deckwer WD. Microbial production of 1,3-propanediol. Appl Microbiol Biotechnol. 1999:52:289-97.

20. Xin B, Wang Y, Tao F, Li L, Ma C, Xu P. Co-utilization of glycerol and lignocellulosic hydrolysates enhances anaerobic 1,3-propanediol production by Clostridium diolis. Sci Rep. 2016:6:19044.

21. Zeng AP, Biebl H. Bulk chemicals from biotechnology: the case of 1,3-propanediol production and the new trends. Adv Biochem Eng Biotechnol. 2002;74:239-59.

22. Zeng AP, Sabra W. Microbial production of diols as platform chemicals: recent progresses. Curr Opin Biotechnol. 2011;22:749-57.

23. Li C, Lesnik KL, Liu H. Microbial conversion of waste glycerol from biodiesel production into value-added products. Energies. 2013;6:4739-68.

24. Koutinas AA, Vlysidis A, Pleissner D, Kopsahelis N, Lopez Garcia I, Kookos IK, Papanikolaou S, Kwan TH, Lin CSK. Valorization of industrial waste and by-product streams via fermentation for the production of chemicals and biopolymers. Chem Soc Rev. 2014:43:2587-627.

25. Zeng AP, Ross A, Biebl H, Tag C, Gunzel B, Deckwer WD. Multiple product inhibition and growth modeling of Clostridium butyricum and Klebsiella pneumoniae in glycerol fermentation. Biotechnol Bioeng. 1994;44:902-11.

26. Menzel K, Zeng AP, Deckwer WD. High concentration and productivity of 1,3-propanediol from continuous fermentation of glycerol by Klebsiella pneumoniae. Enz Microb Technol. 1997;20:82-6.

27. Papanikolaou S, Aggelis G. Modelling aspects of the biotechnological valorization of raw glycerol: production of citric acid by Yarrowia lipolytica 
and 1,3-propanediol by Clostridium butyricum. J Chem Technol Biotechnol. 2003;78:542-7.

28. Papanikolaou S, Fick M, Aggelis G. The effect of raw glycerol concentration on the production of 1,3-propanediol by Clostridium butyricum. J Chem Technol Biotechnol. 2004;79:1 189-96.

29. Willke T, Vorlop K. Biotransformation of glycerol into 1,3-propanediol. Eur J Lipid Sci Technol. 2008;110:831-40.

30. Rossi DM, Da Costa JB, De Souza EA, Peralba MCR, Ayub MAZ. Bioconversion of residual glycerol from biodiesel synthesis into 1,3-propanediol and ethanol by isolated bacteria from environmental consortia. Renew Energy. 2012:39:223-7.

31. Da Silva GP, De Lima CJB, Contiero J. Production and productivity of 1,3-propanediol from glycerol by Klebsiella pneumoniae GLC29. Catal Today. 2015;257:259-66.

32. Papanikolaou S, Fakas S, Fick M, Chevalot I, Panayotou MG, Komaitis M, Marc I, Aggelis G. Biotechnological valorization of raw glycerol discharged after bio-diesel (fatty acid methyl esters) manufacturing process: production of 1,3-propanediol, citric acid and single cell oil. Biomass Bioenergy. 2008;32:60-71.

33. Hirschmann S, Baganz K, Koschik I, Vorlop KD. Development of an integrated bioconversion process for the production of 1,3-propanediol from raw glycerol waters. Landbauforschung Völkenrode. 2005;55:261-7.

34. Chatzifragkou A, Dietz D, Komaitis M, Zeng AP, Papanikolaou S. Effect of biodiesel-derived waste glycerol impurities on biomass and 1,3-propanediol production of Clostridium butyricum VPI 1718. Biotechnol Bioeng. 2010;107(1):75-84.

35. Chatzifragkou A, Papanikolaou S, Dietz D, Doulgeraki Al, Nychas GJE, Zeng AP. Production of 1,3-propanediol by Clostridium butyricum growing on biodiesel-derived crude glycerol through a non-sterilized fermentation process. Appl Microbiol Biotechnol. 2011;91:101-12.

36. Chatzifragkou A, Aggelis G, Komaitis M, Zeng AP, Papanikolaou S. Impact of anaerobiosis strategy and bioreactor geometry on the biochemical response of Clostridium butyricum VPI 1718 during 1,3-propanedio fermentation. Bioresour Technol. 2011;102:10625-32.

37. Wilkens E, Ringel AK, Hortig D, Willke T, Vorlop KD. High-level production of 1,3-propanediol from crude glycerol by Clostridium butyricum AKR102a. Appl Microbiol Biotechnol. 2012;93:1057-63.

38. Nakas JP, Schaedle M, Parkinson CM, Coonley CE, Tanenbaum SW. System-development for linked-fermentation production of solvents from algal biomass. Appl Environ Microbiol. 1983;46:1017-23.

39. Casali S, Gungormusler M, Bertin L, Fava F, Azbar N. Development of a biofilm technology for the production of 1,3-propanediol (1,3-PDO) from crude glycerol. Biochem Eng J. 2012;64:84-90.

40. Boenigk R, Bowien S, Gottschalk G. Fermentation of glycerol to 1,3-propanediol in continuous cultures of Citrobacter freundii. Appl Microbiol Biotechnol. 1993;38:453-7.

41. Metsoviti M, Zeng AP, Koutinas AA, Papanikolaou S. Enhanced 1,3-propanediol production by a newly isolated Citrobacter freundii strain cultivated on biodiesel-derived waste glycerol through sterile and non-sterile bioprocesses. J Biotechnol. 2013;163:408-18.

42. Hartlep M, Hussmann W, Prayitno N, Meynial-Salles I, Zeng AP. Study of two-stage processes for the microbial production of 1,3-propanediol from glucose. Appl Microbiol Biotechnol. 2002;60:60-6.

43. Cervin MA, Soucaille P, Valle F. Process for the biological production of 1,3-propanediol with high yield. EI DuPont de Nemours \& Co. Patent US 2004/0152174 A1. http://www.google.ch/patents/US20040152174 of subordinate document. Accessed 6 Feb 2017.

44. Rodriguez A, Wojtusik M, Masca F, Santos VE, Garcia-Ochoa F. Kinetic modeling of 1,3-propanediol production from raw glycerol by Shimwellia blattae: influence of the initial substrate concentration. Biochem Eng J. 2017;117:57-65

45. Pflügl S, Marx H, Mattanovich D, Sauer M. 1,3-Propanediol production from glycerol with Lactobacillus diolivorans. Bioresour Technol. 2012;1 19:133-40.

46. Wang S, Qiu L, Dai H, Zeng X, Fang B. Highly pure 1,3-propanediol: separation and purification from crude glycerol-based fermentation. Eng Life Sci. 2015;00:1-9.

47. Li ZG, Sun YQ, Zheng WL, Teng H, Xiu ZL. A novel and environmentfriendly bioprocess of 1,3-propanediol fermentation integrated with aqueous two-phase extraction by ethanol/sodium carbonate system. Biochem Eng J. 2013;80:68-75.
48. Anggraini D, Bahagia J, Batubara F. Fermentation of glycerol from biodiesel waste to 1,3-propanediol by Enterobacter Aerogenes. In: Proceedings of the 5th Sriwijaya international seminar on energy and environmental science \& technology; 2014. http://ejournal.unsri.ac.id/index. php/siseest/article/view/1639 of subordinate document. Accessed 6 Feb 2017.

49. Saxena RK, Anand P, Saran S, Isar J. Microbial production of 1,3-propanediol: recent developments and emerging opportunities. Biotechnol Adv. 2009;27:895-913.

50. Xiu ZL, Zeng AP. Present state and perspective of downstream processing of biologically produced 1,3-propanediol and 2,3-butanediol. Appl Microbiol Biotechnol. 2008;78:917-26.

51. Broekhuis RR, Lynn S, King CJ. Recovery of propylene glycol from dilute aqueous solutions by complexation with organoboronates in ion-pair extractants. Ind Eng Chem Res. 1996;35:1206-14.

52. Malinowski JJ. Evaluation of liquid extraction potentials for downstream separation of 1,3-propanediol. Biotechnol Tech. 1999;13:127-30.

53. Hilaly AK, Binder TP. Method of recovering 1,3-propanediol from fermentation broth; 2002. US Patent 6, 479,716.

54. Adkesson DM, Alsop AW, Ames TT, Chu LA, Disney JM, Dravis BC, Fitzgibbon P, Gaddy JM, Gallagher FG, Lehnhardt WF, Lievense JC, Luyben ML, Seapan M, Trotter RE, Wenndt GM, Yu EK. Purification of biologicallyproduced 1,3-propanediol; 2005. US Patent 20050069997.

55. Wilkins AE, Lowe DJ. Product removal process for use in a biofermentation system; 2004. US Patent 6, 812,000.

56. Cho MH, Joen SI, Pyo SH, Mun S, Kim JH. A novel separation and purification process for 1,3-propanediol. Process Biochem. 2006;41:739-44.

57. Soccol CR, Vandenberghe LPS, Rodrigues C, Pandey A. New perspectives for citric acid production and application. Food Technol Biotechnol. 2006;44:141-9.

58. Karaffa L, Kubicek CP. Aspergillus niger citric acid accumulation: do we understand this well working black box? Appl Microbiol Biotechnol. 2003:61:189-96.

59. Rywińska A, Juszczyk P, Wojtatowicz M, Robak M, Lazar Z, Tomaszewska L, Rymowicz W. Glycerol as a promising substrate for Yarrowia lipolytica biotechnological applications. Biomass Bioenerg. 2013;48:148-66.

60. Rywińska A, Juszczyk P, Wojtatowicz M, RymowiczW. Chemostat study of citric acid production from glycerol by Yarrowia lipolytica. J Biotechnol. 2011;152:54-7.

61. Levinson WE, Kurtzman CP, Kuo TM. Characterization of Yarrowia lipolytica and related species for citric acid production from glycerol. Enzyme Microb Tech. 2007:41:292-5.

62. Max B, Salgado JM, Rodríguez N, Cortés S, Converti A, Domínguez JM. Biotechnological production of citric acid. Braz J Microbiol. 2010;41:862-75.

63. Papanikolaou S, Beopoulos A, Koletti A, Thevenieau F, Koutinas AA, Nicaud JM, Aggelis G. Importance of the methyl-citrate cycle on glycerol metabolism in the yeast Yarrowia lipolytica. J Biotechnol. 2013;168:303-14.

64. Papanikolaou S, Aggelis G. Biotechnological valorization of biodiesel derived glycerol waste through production of single cell oil and citric acid by Yarrowia lipolytica. Lipid Technol. 2009;21:83-7.

65. Ratledge C, Wynn J. The biochemistry and molecular biology of lipid accumulation in oleaginous microorganisms. Adv Appl Microbiol. 2002:51:1-51.

66. Papagianni M. Advances in citric acid fermentation by Aspergillus niger: biochemical aspects, membrane transport and modeling. Biotechnol Adv. 2007;25:244-63.

67. Rywińska A, Rymowicz W, Źarowska B, Skrzypiński A. Comparison of citric acid production from glycerol and glucose by different strains of Yarrowia lipolytica. World J Microbiol Biotechnol. 2010;26:1217-24.

68. Rywińska A, Rymowicz W, Marcinkiewicz M. Valorization of raw glycerol for citric acid production by Yarrowia lipolytica yeast. Electron J Biotechnol. 2010;13:4.

69. Rymowicz W, Rywińska A, Źarowska B, Juszczyk P. Citric acid production from raw glycerol by acetate mutants of Yarrowia lypolitica. Chem Pap. 2006;60:391-4.

70. Rymowicz W, Fatykhova AR, Kamzolova SV, Rywińska A, Morgunov IG. Citric acid production from glycerol-containing waste of biodiesel industry by Yarrowia lipolytica in batch, repeated batch, and cell recycle regimes. Appl Microbiol Biotechnol. 2010;87:971-9. 
71. Rywińska A, Rymowicz W. High-yield production of citric acid by Yarrowia lipolytica on glycerol in repeated-batch bioreactors. J Ind Microbiol Biotechnol. 2010;37:431-5.

72. Kamzolova SV, Fatykhova AR, Dedyukhina EG, Anastassiadis SG, Golovchenko NP, Morgunov IG. Citric acid production by yeast grown on glycerol-containing waste from biodiesel industry. Food Technol Biotechnol. 2011:49:65-74.

73. Morgunov IG, Kamzolova SV, Lunina JN. The citric acid production from raw glycerol by Yarrowia lipolytica yeast and its regulation. Appl Microbiol Biotechnol. 2013;97:7387-97.

74. Sabra W, Bommareddy RR, Maheshwari G, Papanikolaou S, Zeng AP. Substrates and oxygen dependent citric acid production by Yarrowia lipolytica: insights through transcriptome and fluxome analyses. Microb Cell Fact. 2017;16:78.
75. Papanikolaou S, Muniglia L, Chevalot I, Aggelis G, Marc I. Yarrowia lipolytica as a potential producer of citric acid from raw glycerol. JAM. 2002;92:737-44.

76. Da Silva LV, Tavares CB, Amaral PFF, Coelho MAZ. Production of citric acid by Yarrowia lipolytica in different crude glycerol concentrations and in different nitrogen sources. Chem Eng Trans. 2012;27:199-203.

77. André A, Chatzifragkou A, Diamantopoulou P, Sarris D, Philippoussis A, Panayotou-Galiotou M, Komaitis M, Papanikolaou S. Biotechnological conversions of bio-diesel-derived crude glycerol by Yarrowia lipolytica strains. Eng Life Sci. 2009;9(6):468-78.

78. Xu DB, Madrid CP, Röhr M, Kubicek CP. The influence of type and concentration of the carbon source on production of citric acid by Aspergillus niger. Appl Microbiol Biotechnol. 1989;30:553-8.

\section{Submit your next manuscript to BioMed Central and we will help you at every step:}

- We accept pre-submission inquiries

- Our selector tool helps you to find the most relevant journal

- We provide round the clock customer support

- Convenient online submission

- Thorough peer review

- Inclusion in PubMed and all major indexing services

- Maximum visibility for your research

Submit your manuscript at www.biomedcentral com/submit 